\title{
Distribution and abundance of fish and crayfish in a Waikato stream in relation to basin area
}

\section{BRENDAN J. HICKS}

Centre for Biodiversity and Ecology Research

Department of Biological Sciences

The University of Waikato

Private Bag 3105

Hamilton, New Zealand

email: b.hicks@waikato.ac.nz

\begin{abstract}
The aim of this study was to relate the longitudinal distribution of fish and crayfish to increasing basin area and physical site characteristics in the Mangaotama Stream, Waikato region, North Island, New Zealand. Fish and crayfish were captured with two-pass removal electroshocking at 11 sites located in hill-country with pasture, native forest, and mixed land uses within the $21.6 \mathrm{~km}^{2}$ basin. Number of fish species and lineal biomass of fish increased with increasing basin area, but barriers to upstream fish migration also influenced fish distribution; only climbing and non-migratory species were present above a series of small waterfalls. Fish biomass increased in direct proportion to stream width, suggesting that fish used much of the available channel, and stream width was closely related to basin area. Conversely, the abundance of crayfish was related to the amount of edge habitat, and therefore crayfish did not increase in abundance as basin area increased. Densities of all fish species combined ranged from 17 to 459 fish $100 \mathrm{~m}^{-2}$, and biomass ranged from 14 to $206 \mathrm{~g} \mathrm{~m}^{-2}$. Eels dominated the fish assemblages, comprising $85-100 \%$ of the total biomass; longfinned eels the majority of the biomass at most sites. Despite the open access of the lower sites to introduced brown trout, native species dominated all the fish communities sampled.
\end{abstract}

Z02027; published 16 June 2003

Received 6 September 2002; accepted 29 January 2003
Keywords native fish; crayfish; species richness; density; biomass; longitudinal distribution

\section{INTRODUCTION}

Stream discharge, channel width, and water temperature generally increase with increasing basin area, whereas channel gradient decreases (Huet 1959; Illes 1961; Hynes 1970; Osterkamp \& Hedman 1977; Pearson 1992). Longitudinal patterns of fish zonation have been related to changes in stream and river characteristics in general terms (e.g., Huet 1959; Hynes 1970; Hawkes 1975; Oberdorff et al. 1993; Cushing et al. 1995). A variety of physical variables such as elevation, basin area, or distance from the source have been linked to longitudinal patterns of fish distribution in a local, regional, or national context (Hayes et al. 1989; Jowett \& Richardson 1996; Jowett et al. 1996; Richardson \& Jowett 1996; Gehrke \& Harris 2000).

In New Zealand, fish distribution in streams and rivers has been attributed to migration, habitat suitability, introduced fish, and land use. Because about $50 \%$ of the fish fauna is diadromous, the patterns of fish distribution are determined by a combination of habitat suitability and access (Hayes et al. 1989; Hanchet 1990; McDowall 1993; Jowett et al. 1996; Joy et al. 2000). The introduction of salmonids such as brown and rainbow trout (Salmo trutta and Oncorhynchus mykiss) in the late 1800s is suspected by some researchers to have reduced native fish abundance (e.g., McDowall 1984, Townsend \& Crowl 1991; Chadderton \& Allibone 2000), but others disagree (e.g., Allen 1961). Forest clearance and the establishment and maintenance of pasture are believed to have reduced the distribution and abundance of native species such as banded kokopu (Galaxias fasciatus; Hanchet 1990; Swales \& West 1991; Hicks \& McCaughan 1997) and crayfish (Paranephrops planifrons; Parkyn 2000).

The aim of this study was to investigate the relationship between increasing basin area and the longitudinal distribution of fish and crayfish in a 
Waikato stream with reaches flowing through native forest and pasture.

\section{STUDY AREA}

The Mangaotama Stream drains $21.6 \mathrm{~km}^{2}$ of land in the Waikato region in the North Island, New Zealand. The stream is a tributary of the Waipa River, and is approximately $113 \mathrm{~km}$ upstream from the sea by river distance (Fig. 1). Eleven study sites at elevations between about 20 and $170 \mathrm{~m}$ were chosen to reflect a sequence of increasing basin areas with native forest, pasture, or mixed land uses at each site and upstream (Table 1; Fig. 1). These sites were $113.9-124.5 \mathrm{~km}$ from the sea by river distance (Table 1). Three sites were in native forest (NW0.5, NW1, and NW5), three were in pasture (PW1, PW2, and PW5), and five sites (M1, M3, M4, M5, and M8) were downstream of both of pasture and native forest. The first letter of each site code refers to the land use surrounding and upstream of a site $(\mathrm{N}$, native forest; $\mathrm{P}$, pasture; $\mathrm{M}$, mixed pasture and native forest). The letter $\mathrm{W}$ refers to the association of the sites with the Whakakai Stream. This numbering system was devised as part of a suite of studies (e.g.,
Hicks \& McCaughan 1997; Quinn \& Cooper 1997; Quinn et al. 1997), and has been retained for ease of comparison with these studies.

Channel gradients, channel widths, and stream flows were closely related to basin area (Table 1). Between sites M3 and M1, M1 and NW5, NW5 and NW1, and NW1 and NW0.5 (Fig. 1), there are various combinations of waterfalls and steep cascades $2 \mathrm{~m}$ in height. The substrate at the native forest sites (NW0.5-NW5) was predominantly coarse and fine gravels, with some cobbles and little or no sand or mud (Table 2). At pasture sites, the substrate was dominated by cobbles (PW1 and PW2) or coarse gravel (PW5), with mud and sand comprising 15$20 \%$ of the sample area. The gravel and cobble substrates were more embedded at the pasture sites than at the native forest sites or those downstream of both land-use types. At three sites in mixed land use (M1, M3, and M4), the substrate was dominated by gravels, with mud and sand comprising 15-20\% of the sample area. The substrate at site M5 was mostly mud and gravel, and at site M8 was soft, deep mud. Site M8 had dense swamp willow weed (Polygonum salicifolium) at the stream margins, and blunt pondweed (Potamogeton ochreatus), a native submerged macrophyte, occupied the channel.

Table 1 Study sites in the Mangaotama Stream in the Waikato region, North Island, New Zealand, showing physical characteristics, dates of fish sampling, and map references from sheet S14, NZMS 260 (Department of Lands and Survey 1979). *Unpublished data from NIWA, Hamilton.

\begin{tabular}{|c|c|c|c|c|c|c|c|c|c|c|c|}
\hline Site & $\begin{array}{l}\text { Elev- } \\
\text { ation } \\
(\mathrm{m})\end{array}$ & $\begin{array}{l}\text { Distance } \\
\text { by river } \\
\text { from the } \\
\text { sea }(\mathrm{km})\end{array}$ & $\begin{array}{c}\text { Basin } \\
\text { area } \\
\left(\mathrm{km}^{2}\right)\end{array}$ & $\begin{array}{l}\text { Length } \\
\text { fished } \\
\text { (m) }\end{array}$ & $\begin{array}{l}\text { Area } \\
\text { fished } \\
\left(\mathrm{m}^{2}\right)\end{array}$ & $\begin{array}{l}\text { Mean } \\
\text { water } \\
\text { surface } \\
\text { width } \\
\text { (m) }\end{array}$ & $\begin{array}{l}\text { Channel } \\
\text { gradient } \\
\left(\mathrm{m} \mathrm{m}^{-1}\right)^{*}\end{array}$ & $\begin{array}{r}\text { Instant } \\
\text { dischar }\end{array}$ & $\begin{array}{l}\text { aneous } \\
\text { se }\left(1 \mathrm{~s}^{-1}\right) \\
\begin{array}{c}\mathrm{Jan}- \\
\text { Feb }\end{array}\end{array}$ & $\begin{array}{c}\text { Map } \\
\text { reference }\end{array}$ & $\begin{array}{c}\text { Dates } \\
\text { sampled } \\
1993 \text { or } 95\end{array}$ \\
\hline \multicolumn{12}{|c|}{ Native forest upstream } \\
\hline $\begin{array}{l}\text { NW0.5 } \\
\text { NW1 } \\
\text { NW5 }\end{array}$ & $\begin{array}{r}150 \\
100 \\
65\end{array}$ & $\begin{array}{l}123.3 \\
122.5 \\
121.4\end{array}$ & $\begin{array}{l}0.23 \\
0.98 \\
3.17\end{array}$ & $\begin{array}{l}24.3 \\
66.6 \\
54.4\end{array}$ & $\begin{array}{r}17.7 \\
115.8 \\
173.5\end{array}$ & $\begin{array}{l}0.73 \\
1.74 \\
3.19\end{array}$ & $\begin{array}{l}0.0880 \\
0.0190 \\
0.0098\end{array}$ & $\begin{array}{r}3.0 \\
11.0 \\
102.0\end{array}$ & $\begin{array}{r}0.4 \\
11.0 \\
25.8\end{array}$ & $\begin{array}{l}2691363779 \\
2691763785 \\
2692663785\end{array}$ & $\begin{array}{r}18 \text { Jan } 95 \\
4 \text { Feb } 93 \\
17 \text { Jan } 95\end{array}$ \\
\hline \multicolumn{12}{|c|}{ Pasture upstream } \\
\hline $\begin{array}{l}\text { PW1 } \\
\text { PW2 } \\
\text { PW5 }\end{array}$ & $\begin{array}{r}170 \\
100 \\
60\end{array}$ & $\begin{array}{l}124.5 \\
123.4 \\
121.7\end{array}$ & $\begin{array}{l}0.06 \\
0.95 \\
2.59\end{array}$ & $\begin{array}{r}3.7 \\
75.0 \\
47.1\end{array}$ & $\begin{array}{r}1.4 \\
83.5 \\
106.4\end{array}$ & $\begin{array}{l}0.38 \\
1.11 \\
2.26\end{array}$ & $\begin{array}{l}0.1940 \\
0.0320 \\
0.0180\end{array}$ & $\begin{array}{r}2.0 \\
32.9 \\
93.3\end{array}$ & $\begin{array}{r}0.3 \\
16.0 \\
19.6\end{array}$ & $\begin{array}{l}2691463762 \\
2692363764 \\
2692863776\end{array}$ & $\begin{array}{l}31 \text { Jan } 95 \\
22 \text { Jan } 93 \\
16 \text { Jan } 95\end{array}$ \\
\hline \multicolumn{12}{|c|}{ Mixed pasture and native forest upstream } \\
\hline $\begin{array}{l}\text { M1 } \\
\text { M3 } \\
\text { M4 } \\
\text { M5 } \\
\text { M8 }\end{array}$ & $\begin{array}{l}55 \\
35 \\
30 \\
20 \\
20\end{array}$ & $\begin{array}{l}120.9 \\
119.7 \\
119.2 \\
116.2 \\
113.9\end{array}$ & $\begin{array}{r}9.15 \\
15.43 \\
15.95 \\
19.27 \\
21.18\end{array}$ & $\begin{array}{l}51.0 \\
33.4 \\
51.6 \\
39.4 \\
11.0\end{array}$ & $\begin{array}{r}272.9 \\
173.3 \\
205.9 \\
139.1 \\
44.3\end{array}$ & $\begin{array}{l}5.35 \\
5.19 \\
3.99 \\
3.53 \\
4.03\end{array}$ & $\begin{array}{l}0.0160 \\
0.0036 \\
0.0035 \\
0.0015 \\
0.0005\end{array}$ & $\begin{array}{l}224.0 \\
331.0 \\
416.1 \\
490.8 \\
368.8\end{array}$ & $\begin{array}{r}64.8 \\
97.3 \\
106.0 \\
123.5 \\
76.9\end{array}$ & $\begin{array}{l}2693063784 \\
2693763788 \\
2694063789 \\
2695363797 \\
2696363805\end{array}$ & $\begin{array}{l}\text { 19 Jan } 95 \\
\text { 25 Jan } 95 \\
\text { 24 Jan } 95 \\
\text { 30 Jan } 95 \\
\text { 26 Jan } 95\end{array}$ \\
\hline
\end{tabular}


Fig. 1 Location of the study sites and waterfalls, and the distribution of fish and crayfish in the Mangaotama Stream, Waikato region, North Island, New Zealand. Key to site abbreviations: $\mathrm{N}$, sites in native forest; $\mathrm{P}$, sites in pasture; $\mathrm{M}$, sites with a mixture of native forest and pasture upstream.
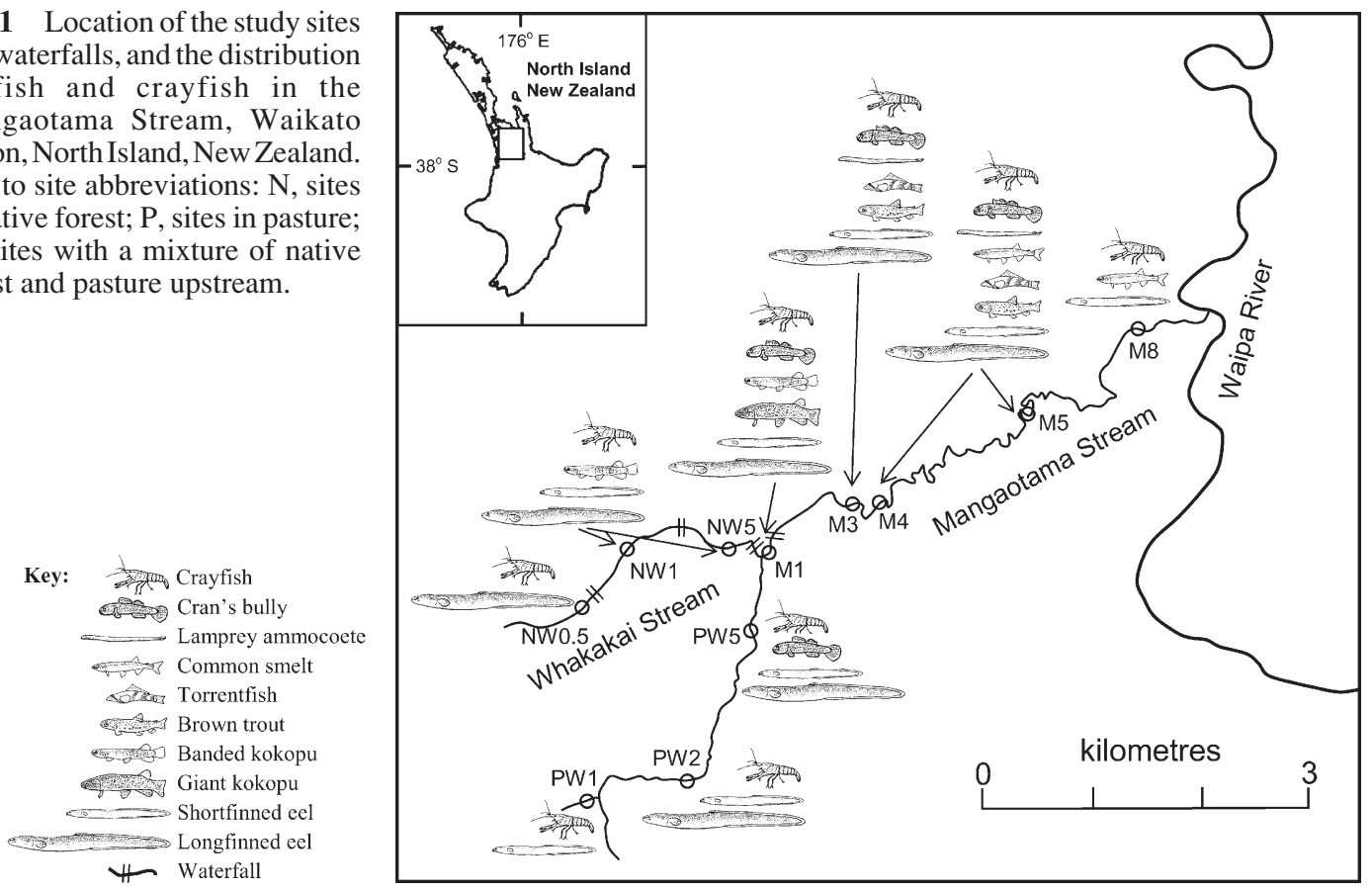

Table 2 Substrate and water quality from 16 January to 4 February at 11 sites on the Mangaotama Stream. -, not measured.

\begin{tabular}{|c|c|c|c|c|c|c|c|c|c|c|c|}
\hline \multirow[b]{2}{*}{ Site } & \multicolumn{7}{|c|}{ Area of streambed occupied by each substrate class (\%) } & \multirow[b]{2}{*}{$\mathrm{pH}$} & \multirow{2}{*}{$\begin{array}{l}\text { Temp- } \\
\text { erature } \\
\left({ }^{\circ} \mathrm{C}\right)\end{array}$} & \multirow{2}{*}{$\begin{array}{c}\text { Con- } \\
\text { ductivity } \\
\left(\mu \mathrm{S} \mathrm{cm}^{-1}\right)\end{array}$} & \multirow{2}{*}{$\begin{array}{c}\text { Total } \\
\text { dissolved } \\
\text { solids } \\
\left(\mathrm{g} \mathrm{m}^{-3}\right)\end{array}$} \\
\hline & Mud & Sand & $\begin{array}{l}\text { Fine } \\
\text { gravel }\end{array}$ & $\begin{array}{l}\text { Coarse } \\
\text { gravel }\end{array}$ & Cobble & Boulder & Bedrock & & & & \\
\hline \multicolumn{12}{|c|}{ Native forest upstream } \\
\hline NW0.5 & 5 & 10 & 15 & 45 & 10 & 15 & 0 & 7.8 & 15.6 & 148 & 74.0 \\
\hline NW1 & 0 & 5 & 30 & 50 & 15 & 0 & 0 & - & 11.7 & - & - \\
\hline NW5 & 0 & 0 & 20 & 60 & 10 & 10 & 0 & 7.5 & 16.9 & 139 & 66.3 \\
\hline \multicolumn{12}{|c|}{ Pasture upstream } \\
\hline PW1 & 10 & 10 & 10 & 10 & 45 & 10 & 5 & 7.0 & 17.7 & 158 & 68.7 \\
\hline PW2 & 20 & 0 & 0 & 10 & 30 & 40 & 0 & - & 18.0 & - & - \\
\hline PW5 & 10 & 5 & 20 & 50 & 5 & 0 & 10 & 8.0 & 21.1 & 131 & 65.6 \\
\hline \multicolumn{12}{|c|}{ Mixed pasture and native forest upstream } \\
\hline M1 & 10 & 5 & 25 & 40 & 0 & 0 & 20 & 8.0 & 18.5 & 134 & 67.1 \\
\hline M3 & 10 & 10 & 50 & 30 & 0 & 0 & 0 & 8.0 & 18.2 & 128 & 64.1 \\
\hline M4 & 10 & 5 & 15 & 70 & 0 & 0 & 0 & 7.8 & 19.6 & 130 & 64.9 \\
\hline M5 & 60 & 10 & 20 & 10 & 0 & 0 & 0 & 7.8 & 23.8 & 129 & 64.0 \\
\hline M8 & 90 & 10 & 0 & 0 & 0 & 0 & 0 & 8.0 & 20.9 & 128 & 64.1 \\
\hline
\end{tabular}




\section{METHODS}

Fish and crayfish densities were estimated at each site between 16 January and 4 February over 2 years (Table 1). I used a $90 \mathrm{~W}$ backpack electroshocker, powered by $12 \mathrm{~V}$ battery, and made two passes per site fishing in an upstream direction. To catch fish and crayfish, 5-mm-mesh stop nets were placed across the channel at the upstream and downstream ends of stream sections that were between 3.7 and $75 \mathrm{~m}$ long. Fish and crayfish captured in each pass were processed separately. Each fish was identified to species, measured, and weighed. Length measurements were defined as total length (TL) for eels, bullies, and lamprey ammocoetes and fork length (FL) for the kokopu species, torrentfish, smelt, and brown trout. For crayfish, the orbit-carapace length (OCL) was measured as the distance from the back of the eye orbit to the distal end of the carapace with Vernier-scale callipers.

Numbers and biomass of fish in the stream sections were calculated from the two-pass removal estimates using the formula:

$$
\hat{N}=\frac{U_{1}}{1-\left(\frac{U_{2}}{U_{1}}\right)}
$$

where $\widehat{N}=$ total number or biomass of fish, $U_{1}=$ number or weight of fish caught on the first pass, and $U_{2}=$ number or weight of fish caught on the second pass (White et al. 1982; Armour et al. 1983). Variance was calculated using a formula given by Armour et al. (1983):

$$
\operatorname{Variance}(\hat{N})=\frac{\left(U_{1}+U_{2}\right)\left(1-\frac{U_{1}+U_{2}}{\hat{N}}\right)}{\left(\frac{U_{1}+U_{2}}{\hat{N}}\right)^{2}-(2 \hat{p})^{2}(1-\hat{p})}
$$

and the square root of the variance was used as the standard error of $\widehat{N}$.

The capture probability, $\hat{p}$, was estimated as:

$$
\hat{p}=1-\frac{U_{2}}{U_{1}}
$$

At all sites but one, two passes were sufficient to produce an estimate of fish abundance. Site PW1 was so shallow $(0.02-0.04 \mathrm{~m})$ that electroshocking was very inefficient, and the site had to be picked apart by hand to recover crayfish and any fish buried in crevices between cobbles and gravel. For this reason, the section was very short $(3.7 \mathrm{~m})$, and the sum of the fish and crayfish captured by electroshocking and hand capture were used as the population estimate. This sampling method was considered equivalent to successful removal estimates from electroshocking at the other study sites.

Where a population estimate for an individual species failed because there was no reduction between the first and second passes, the sum of the two passes was used as the estimate. This was necessary only for crayfish at the sites NW5 and M8. All fish were taken back to the laboratory for further analysis, where the identity of the bully species was confirmed. The biomass of fish and crayfish was estimated by multiplying density by mean weights at each site.

The 1993 estimates of fish and crayfish abundance for sites NW1 and PW2 were taken from Hicks \& McCaughan (1997), and these sites were not resampled in 1995. The fish density estimates given here are slightly different from those cited in Hicks \& McCaughan (1997) because a different method was used to calculate the density of all species combined. Hicks \& McCaughan calculated the removal estimate from the total of fish on the first pass and the total on the second pass, whereas in this study, numbers were calculated for each species separately, and densities of all species combined were calculated from the sum of these individually calculated densities.

Gradient, mean water surface width, and stream discharge were measured at each site. Gradient was measured with a surveyor's level and staff at each site (Quinn et al. 1997). Mean water surface widths were calculated from 10 measurements at each site, and stream discharge was estimated from the summation of measurements of water column depth and mean velocity at 5-10 points across the stream at each site. Discharge was measured in both November 1993 (NIWA unpubl. data) and JanuaryFebruary 1993 or 1995 . The area of streambed occupied by each of seven substrate classes and substrate embeddedness was estimated visually at each site (Table 2). Water temperature was measured once at each site at between 1200 and $1500 \mathrm{~h}$. Conductivity, total dissolved solids, and $\mathrm{pH}$ were measured at most sites with a Toledo Checkmate 90 meter with interchangeable sensors. Regressions were calculated by the least-squares method, and Pearson correlations are reported. These statistics were calculated using SYSTAT version 10 (SPSS 2000). 


\section{RESULTS}

\section{Physical characteristics}

The physical characteristics of the sites were influenced by both basin size and land use. Discharge measured in both November and January-February increased with basin area (Table 3 ). Water width also increased with basin area (Table 3; Fig. 2A), but channel gradient was inversely related to basin area (Table 3; Fig. 2B). Spot water temperatures were lower at sites downstream from the native forest than at sites downstream of pasture or both mixed landuse types (Table 2; Kruskal-Wallis test, $P=0.037$ ). Water temperatures at sites M1 and M3 were lower than at the upstream pasture sites (PW1-PW5), probably because of the influence of cool water from the forested Whakakai Stream. Conductivity ranged from 128 to $158 \mu \mathrm{S} \mathrm{cm}^{-1}$ (Table 2).

\section{Fish and crayfish abundance}

A total channel length of $458 \mathrm{~m}\left(1334 \mathrm{~m}^{2}\right)$ was sampled, and 957 fish comprising nine species of fish were caught. Shortfinned eels (Anguilla australis) and longfinned eels (A. dieffenbachii) were the most numerous native fish species caught, followed by lamprey ammocoetes (Geotria australis), Cran's bullies (Gobiomorphus basalis), common smelt (Retropinna retropinna), torrentfish (Cheimarrichthys fosteri), banded kokopu, and giant kokopu (Galaxias argenteus). Longfinned and shortfinned eels were the most widely distributed fish, and were found at almost every site (Fig. 1). The introduced brown trout was found at two sites. Crayfish were found at every site, and a total of 690 was caught.

Fig. 2 The relationships of water width and channel gradient to basin area in the Mangaotama Stream.
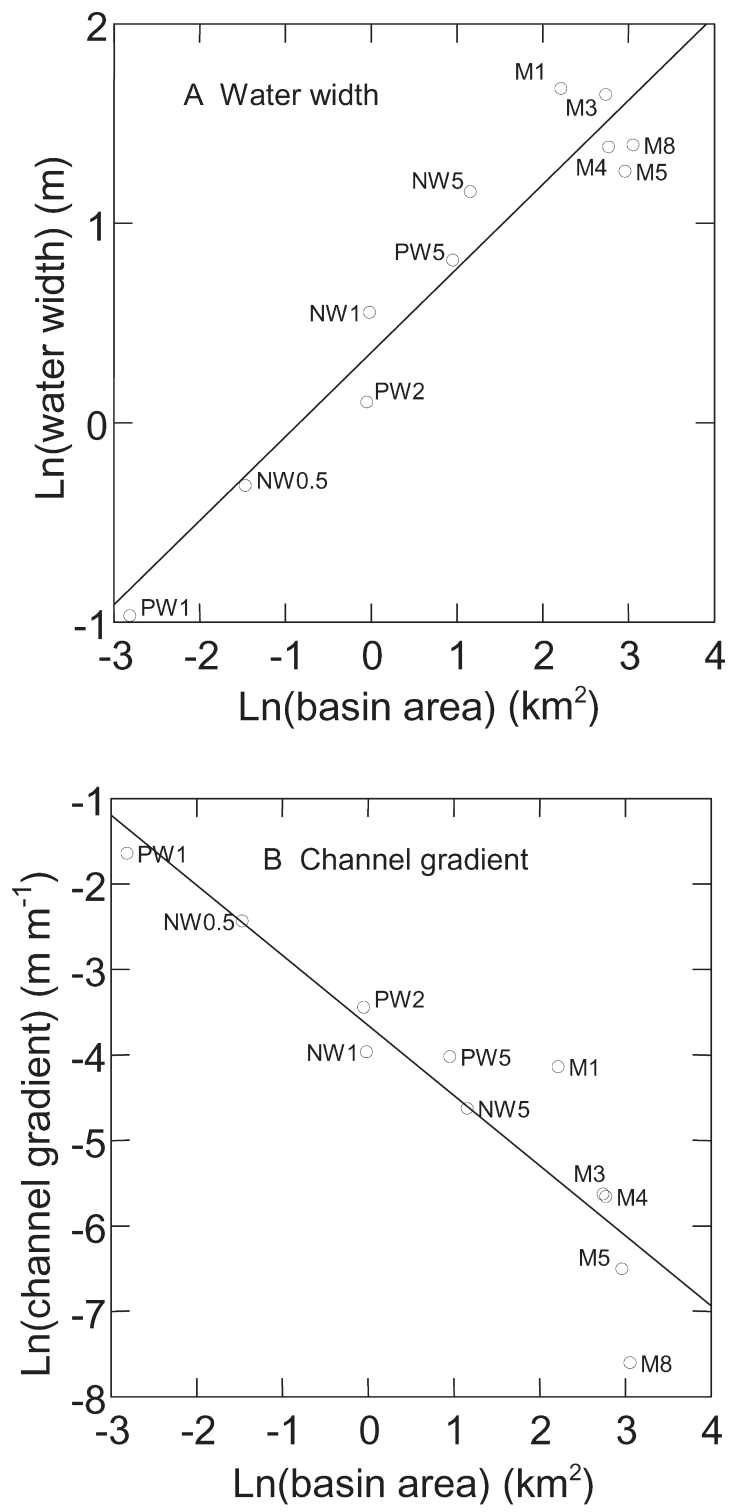

Table 3 Regression relationships of basin area to physical attributes and abundance of fish and crayfish in the Mangaotama Stream at 11 sites. *Site M8 excluded because of substrate difference.

\begin{tabular}{|c|c|c|c|c|c|c|}
\hline $\begin{array}{l}\text { Dependent } \\
\text { variable }(Y)\end{array}$ & $\begin{array}{l}\text { Independent } \\
\text { variable }(X)\end{array}$ & $n$ & $a$ & $b$ & $r^{2}$ & $P$ \\
\hline $\ln \left(\right.$ discharge in Nov litre $\left.\mathrm{s}^{-1}\right)$ & $\ln \left(\right.$ basin area in $\left.\mathrm{km}^{2}\right)$ & 11 & 3.15 & 1.003 & 0.96 & $<0.001$ \\
\hline $\ln \left(\right.$ discharge in Jan-Feb litre $\left.\mathrm{s}^{-1}\right)$ & $\ln \left(\right.$ basin area in $\left.\mathrm{km}^{2}\right)$ & 11 & 1.79 & 1.051 & 0.93 & $<0.001$ \\
\hline $\ln ($ water width $\mathrm{m})$ & $\ln \left(\right.$ basin area in $\left.\mathrm{km}^{2}\right)$ & 11 & 0.352 & 0.423 & 0.92 & $<0.001$ \\
\hline $\ln \left(\right.$ channel gradient $\left.\mathrm{m} \mathrm{m}^{-1}\right)$ & $\ln \left(\right.$ basin area in $\mathrm{km}^{2}$ ) & 11 & -3.66 & -0.821 & 0.85 & $<0.001$ \\
\hline $\ln$ (number of fish species) & $\ln \left(\right.$ basin area in $\left.\mathrm{km}^{2}\right)$ & $10^{*}$ & 0.798 & 0.344 & 0.93 & $<0.001$ \\
\hline $\ln \left(\right.$ number of fish $\left.100 \mathrm{~m}^{-1}\right)$ & basin area in $\mathrm{km}^{2}$ & 11 & 3.41 & 0.175 & 0.86 & $<0.001$ \\
\hline $\ln$ (biomass of fish $\mathrm{g} \mathrm{m}^{-1}$ ) & $\ln \left(\right.$ basin area in $\left.\mathrm{km}^{2}\right)$ & 11 & 3.58 & 0.603 & 0.77 & $<0.001$ \\
\hline $\ln \left(\right.$ number of crayfish $100 \mathrm{~m}^{-2}$ ) & $\ln \left(\right.$ basin area in $\mathrm{km}^{2}$ ) & 11 & 5.22 & -0.464 & 0.69 & 0.001 \\
\hline
\end{tabular}


Table 4 Density of fish and number of fish species in the Mangaotama Stream. -, species not present.

\section{Density (fish $100 \mathrm{~m}^{-2}$ )}

\begin{tabular}{|c|c|c|c|c|c|c|c|c|c|c|c|}
\hline Site & $\begin{array}{l}\text { Long- } \\
\text { finned } \\
\text { eel }\end{array}$ & $\begin{array}{l}\text { Short- } \\
\text { finned } \\
\text { eel }\end{array}$ & $\begin{array}{l}\text { Cran's } \\
\text { bully }\end{array}$ & $\begin{array}{l}\text { Common } \\
\text { smelt }\end{array}$ & $\begin{array}{l}\text { Banded } \\
\text { kokopu }\end{array}$ & $\begin{array}{c}\text { Giant } \\
\text { kokopu }\end{array}$ & $\begin{array}{l}\text { Torrent- } \\
\text { fish }\end{array}$ & Lamprey & $\begin{array}{l}\text { Brown } \\
\text { trout }\end{array}$ & Total & $\begin{array}{c}\text { Number } \\
\text { of } \\
\text { species }\end{array}$ \\
\hline \multicolumn{12}{|c|}{ Native forest upstream } \\
\hline NW0.5 & 16.9 & - & - & - & - & - & - & - & - & 16.9 & 1 \\
\hline NW1 & 9.6 & 0.9 & - & - & 3.9 & - & - & - & - & 14.3 & 3 \\
\hline NW5 & 10.4 & 3.5 & - & - & 0.6 & - & - & - & - & 14.4 & 3 \\
\hline \multicolumn{12}{|c|}{ Pasture upstream } \\
\hline PW1 & - & 70.7 & - & - & - & - & - & - & - & 70.7 & 1 \\
\hline PW2 & 18.1 & 98.6 & - & - & - & - & - & - & - & 116.6 & 2 \\
\hline PW5 & 3.8 & 31.6 & 3.8 & - & - & - & - & - & - & 39.1 & 3 \\
\hline \multicolumn{12}{|c|}{ Mixed pasture and native forest upstream } \\
\hline M1 & 8.5 & 10.3 & 1.8 & - & 0.4 & 0.4 & - & - & - & 21.4 & 4 \\
\hline M3 & 13.6 & 15.3 & 26.0 & - & - & - & 2.6 & 1.7 & - & 59.2 & 5 \\
\hline M4 & 23.4 & 40.9 & 46.2 & 6.6 & - & - & 3.0 & 22.4 & 0.5 & 143.0 & 7 \\
\hline M5 & 31.7 & 61.0 & 8.8 & 2.9 & - & - & 0.7 & 98.8 & 2.2 & 206.0 & 7 \\
\hline M8 & - & 452.3 & - & 6.8 & - & - & - & - & - & 459.1 & 2 \\
\hline
\end{tabular}

Table 5 Biomass of fish in the Mangaotama Stream. -, species not present.

\begin{tabular}{|c|c|c|c|c|c|c|c|c|c|c|}
\hline \multirow[b]{2}{*}{ Site } & \multicolumn{10}{|c|}{ Biomass $\left(\mathrm{g} \mathrm{m}^{-2}\right)$} \\
\hline & $\begin{array}{l}\text { Long- } \\
\text { finned } \\
\text { eel }\end{array}$ & $\begin{array}{l}\text { Short- } \\
\text { finned } \\
\text { eel }\end{array}$ & $\begin{array}{l}\text { Cran's } \\
\text { bully }\end{array}$ & $\begin{array}{c}\text { Common } \\
\text { smelt }\end{array}$ & $\begin{array}{l}\text { Banded } \\
\text { kokopu }\end{array}$ & $\begin{array}{c}\text { Giant } \\
\text { kokopu }\end{array}$ & $\begin{array}{l}\text { Torrent- } \\
\text { fish }\end{array}$ & Lamprey & $\begin{array}{c}\text { Brown } \\
\text { trout }\end{array}$ & Total \\
\hline \multicolumn{11}{|c|}{ Native forest upstream } \\
\hline NW0.5 & 21.3 & - & - & - & - & - & - & - & - & 21.3 \\
\hline NW1 & 17.4 & 0.4 & - & - & 3.1 & - & - & - & - & 20.9 \\
\hline NW5 & 13.8 & 0.2 & - & - & 0.1 & - & - & - & - & 14.0 \\
\hline \multicolumn{11}{|c|}{ Pasture upstream } \\
\hline PW1 & - & 16.5 & - & - & - & - & - & - & - & 16.5 \\
\hline PW2 & 53.4 & 20.9 & - & - & - & - & - & - & - & 74.3 \\
\hline PW5 & 5.5 & 8.0 & 0.1 & - & - & - & - & - & - & 13.6 \\
\hline \multicolumn{11}{|c|}{ Mixed pasture and native forest upstream } \\
\hline M1 & 26.1 & 1.6 & 0.03 & - & 0.002 & 0.8 & - & - & - & 28.6 \\
\hline M3 & 12.9 & 0.6 & 0.6 & - & - & - & 0.2 & - & - & 14.3 \\
\hline M4 & 48.0 & 2.4 & 1.2 & 0.4 & - & - & 0.5 & 0.2 & 0.1 & 52.8 \\
\hline M5 & 32.8 & 8.4 & 0.2 & 0.1 & - & - & 0.3 & 1.2 & 5.6 & 48.6 \\
\hline M8 & - & 205.6 & - & 0.2 & - & - & - & - & - & 205.8 \\
\hline
\end{tabular}

At sites M3 and M5 a total of 15 shrimp (Paratya curvirostris) was caught (Table 4).

Fish densities varied widely between sites, from 14.4 to a maximum of 452 fish $100 \mathrm{~m}^{-2}$ for shortfinned eels at the most downstream site (M8; Table 4). Banded and giant kokopu were scarce $(0.4$ 3.9 fish $100 \mathrm{~m}^{-2}$ ), and found only at forested sites
(NW1 and NW5) or at sites with heavy riparian shade (M1). One adult giant kokopu (238 mm FL) and one upstream-migrant banded kokopu (43 mm FL) were found at site M1, close to the confluence of the forested Whakakai Stream (Fig. 1). Cran's bullies and lamprey ammocoetes were very abundant at several sites downstream from mixed land uses. 
Common smelt, torrentfish, lampreys, and brown trout were absent upstream of the 2-m waterfall between M1 and M3. This waterfall prevented further upstream migration of these species, all of which (except brown trout) are obligately diadromous in river systems.

Most shortfinned eels were small ( $<200 \mathrm{~mm}$ TL), whereas longfinned eels were larger, reaching a maximum of $>1000 \mathrm{~mm}$ TL (Fig. 3). Ammocoetes, the only life stage of lamprey found, had a modal length of 90-95 mm. Two cohorts of Cran's bullies appeared to be present, but relatively few of the age0 cohort were caught, probably because of inefficient sampling of these very small fish.

Longfinned eels comprised most of the fish biomass at all sites except PW1 and M8, where they were absent (Table 5). At site M8, the biomass of shortfinned eels was very high $\left(206 \mathrm{~g} \mathrm{~m}^{-2}\right)$. Lamprey ammocoetes were abundant at M4 and M5 but contributed a small amount of biomass because of their small size (mean weight $0.86-1.23 \mathrm{~g}$ ).

Crayfish lineal densities were similar between sites, but areal densities were greatest in the smallest tributaries (Table 6). Two cohorts were evident at pasture and mixed land-use sites, but only one positively skewed cohort at native forest sites (Fig. 4). Thus, crayfish grew to larger sizes at pasture and mixed land-use sites than at native forest sites (Kruskal-Wallis test; $P<0.001$ ).

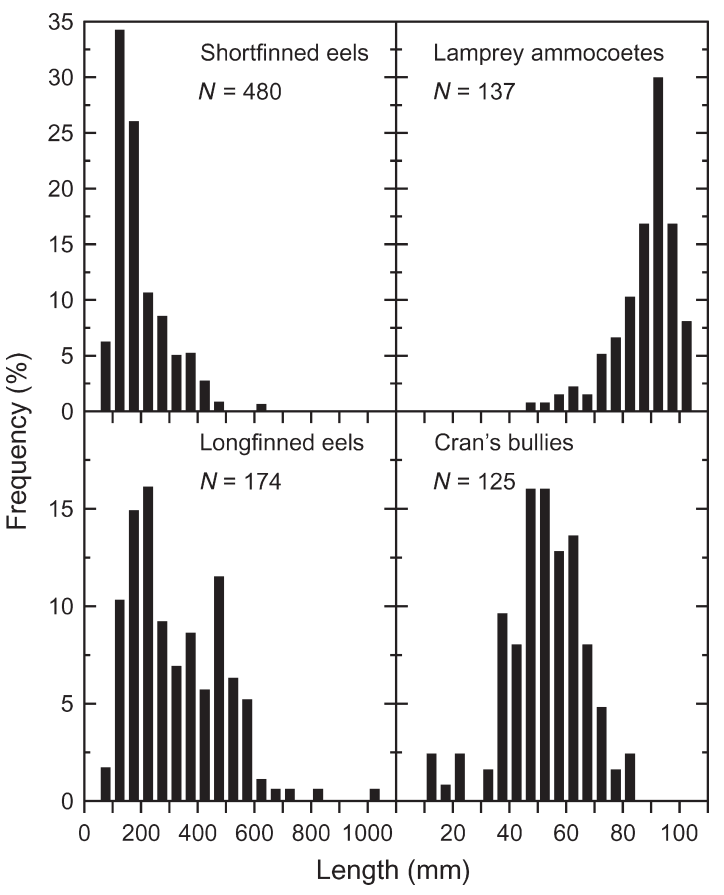

Fig. 3 Length frequencies of eels, lamprey ammocoetes, and Cran's bullies in the Mangaotama Stream.

Table 6 Mean individual weight, density, and biomass of crayfish in the Mangaotama Stream.

\begin{tabular}{|c|c|c|c|c|c|}
\hline \multirow[b]{2}{*}{ Site } & \multirow[b]{2}{*}{$\begin{array}{l}\text { Mean individual } \\
\text { weight }(\mathrm{g})\end{array}$} & \multicolumn{2}{|c|}{ Density } & \multicolumn{2}{|c|}{ Biomass } \\
\hline & & $\begin{array}{l}\text { Number } \\
100 \mathrm{~m}^{-1}\end{array}$ & $\begin{array}{l}\text { Number } \\
100 \mathrm{~m}^{-2}\end{array}$ & $\mathrm{~g} \mathrm{~m}^{-1}$ & $\mathrm{~g} \mathrm{~m}^{-2}$ \\
\hline \multicolumn{6}{|c|}{ Native forest upstream } \\
\hline NW0.5 & 2.9 & 304 & 417 & 9.0 & 12.3 \\
\hline NW1 & 2.1 & 938 & 540 & 19.5 & 11.2 \\
\hline NW5 & 2.9 & 129 & 40 & 3.7 & 1.1 \\
\hline \multicolumn{6}{|c|}{ Pasture upstream } \\
\hline PW1 & 5.8 & 270 & 711 & 15.8 & 41.5 \\
\hline PW2 & 2.1 & 182 & 163 & 3.8 & 3.4 \\
\hline PW5 & 3.8 & 96 & 42 & 3.7 & 1.6 \\
\hline \multicolumn{6}{|c|}{ Mixed pasture and native forest upstream } \\
\hline M1 & 5.0 & 460 & 86 & 23.1 & 4.3 \\
\hline M3 & 5.6 & 480 & 92 & 26.9 & 5.2 \\
\hline M4 & 5.8 & 225 & 56 & 12.9 & 3.2 \\
\hline M5 & 8.0 & 143 & 41 & 11.5 & 3.3 \\
\hline M8 & 4.1 & 209 & 52 & 8.6 & 2.1 \\
\hline
\end{tabular}




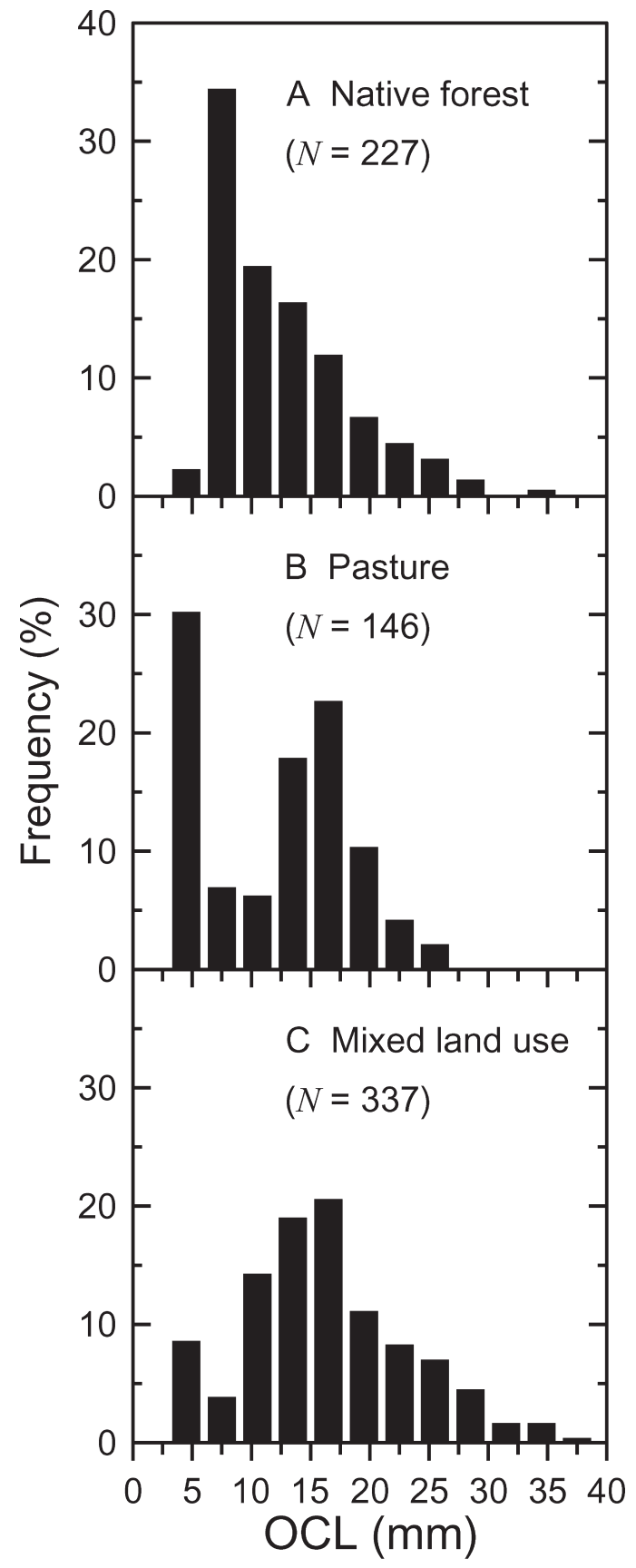

Fig. 4 Length frequencies of crayfish in A, native forest; $\mathbf{B}$, pasture; and $\mathbf{C}$, mixed land use in the Mangaotama Stream. OCL, orbit-carapace length.

\section{Influence of basin area}

The number of fish species at each site increased from upstream to downstream. Only one species was caught at the most upstream sites, but seven species at sites M4 and M5 (Table 4; Fig. 5A). There was a significant regression relationship between the number of fish species and basin area, with M8 excluded (Table 3). Site M8 was excluded from the regression on the basis of a distinct habitat change from gravel substrates at the upstream sites to a substrate of soft mud with rooted aquatic macrophytes at site M8.

The regression relationships between lineal fish abundance and basin area were highly significant (Table 3). Lineal fish density and biomass increased with increasing basin area (Fig. 5B,C), whereas areal density of crayfish decreased as basin area increased (Fig. 5D; Table 3).

\section{DISCUSSION}

Longitudinal patterns of fish distribution and abundance in the Mangaotama Stream were related to basin area; fish density, biomass, and number of species increased with increasing basin area. Stream discharge and width also increased with increasing basin area. Basin area has some advantages over measurements of stream width in predicting longitudinal fish distribution. Firstly, basin area can be accurately determined from maps without the need for field measurements with their associated errors. Secondly, basin area is not affected by localised changes in stream width that might obscure patterns of increasing fish biomass with increasing stream size. For instance, in basins $<10 \mathrm{~km}^{2}$ in area in the Waikato region, stream width is narrower in pasture than native forest (Davies-Colley 1997).

This paper gives both lineal and areal measures for density and biomass because most previous studies have reported only areal measures. Also, lineal measures are more appropriate to investigate the response of fish and crayfish abundance to basin area because there was a simple, direct correlation between stream width and basin area. For fish, lineal measures (fish $\mathrm{m}^{-1}$ ) showed the most contrast between the sites. Areal measures of abundance (fish $\mathrm{m}^{-2}$ ) masked changes in lineal fish abundance because of changes in stream width.

Access for migratory fish appeared to determine the number of fish species in the Mangaotama Stream. This is similar to Taranaki Ring Plain rivers, 

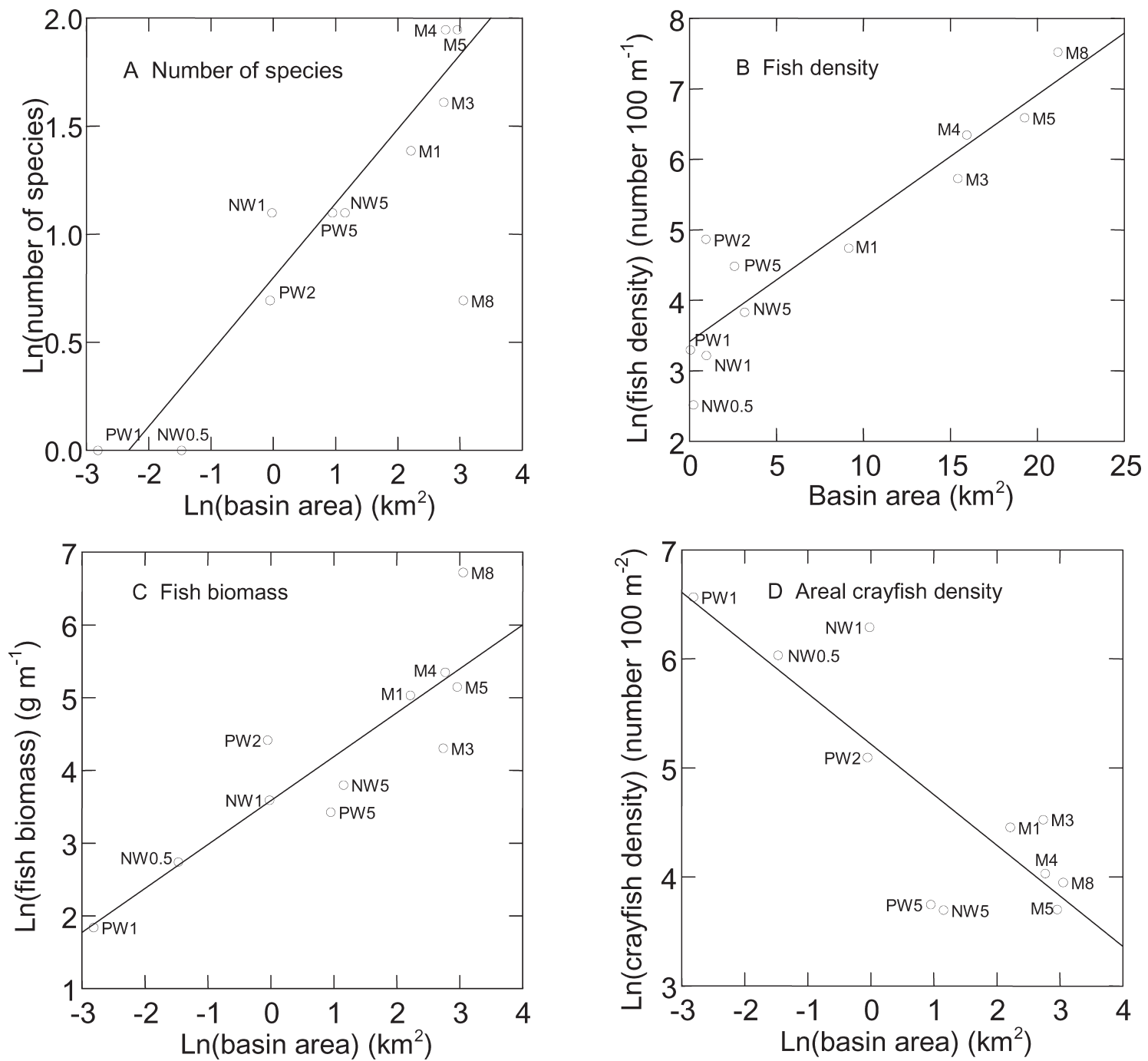

Fig. 5 The relationships of $\mathbf{A}$, number of fish species; $\mathbf{B}$, fish density; $\mathbf{C}$, fish biomass; and $\mathbf{D}$, crayfish density to basin area in the Mangaotama Stream. N, native forest sites; P, pasture sites; M, sites with mixed pasture and native forest upstream. Site M8 was excluded from the regression analysis in Fig. 5A because of substrate differences.

where diadromy was the strongest factor controlling fish community structure (Joy et al. 2000). Access becomes progressively more difficult with increasing distance upstream as channel gradients and barriers to migration increase. Close to the coast, channel gradients are slight and barriers are few. The Mangaotama Stream is relatively far inland $(113 \mathrm{~km}$ by river from the sea), and had few fish species (14 fish species per site; Hicks \& McCaughan 1997). Similar sites on east coast streams in the North Island that were $<50 \mathrm{~km}$ from the coast had 5-7 fish species per site (Rowe et al. 1999). The fish species found in the Mangaotama Stream differ in their migratory ability. Eels and banded kokopu can surmount waterfalls and cascades to penetrate further inland, whereas other species cannot (Boubée et al. 1999). Only the non-migratory Cran's bully and the climbing species (longfinned eels, shortfinned eels, and banded kokopu) were found at sites above waterfalls. The absence of common smelt, 
torrentfish, lampreys, and brown trout upstream of site M3 suggests that the 2-m waterfall between M1 and M3 prevented further upstream migration of these species, which are all (except brown trout) obligately diadromous in river systems.

The positive relationship between the number of fish species and increasing basin area in the Mangaotama Stream is a common feature of streams both in New Zealand and overseas (e.g., Oberdorff et al. 1993; Dudgeon 1995; Jowett et al. 1996; Richardson \& Jowett 1996; Gehrke \& Harris 2000). In New Zealand, the number of fish species richness is inversely related to site elevation and distance to the sea (Hayes et al. 1989; Jowett et al. 1996; Richardson \& Jowett 1996). To some extent these site characteristics are related to basin area, because lower elevation sites are usually closer to the sea (Richards 1982). Galaxiids were less abundant in the Mangaotama Stream than in the nearly pristine Maori River on Stewart Island, New Zealand (Chadderton \& Allibone 2000). Whether this reflects the widespread habitat modification and large number of introduced fish species in the Waikato River system (Chapman 1996), or the greater distance to the sea of the Mangaotama Stream sites, is not clear. In south-eastern Australian rivers, the number of fish species rapidly reached a maximum within $100 \mathrm{~km}$ from the source, with little increase in number of species thereafter (Gehrke \& Harris 2000). In the Seine and its tributaries, beyond a certain point the number of fish species also decreased with increasing basin area, possibly due to habitat changes in the lower reaches (Oberdorff et al. 1993).

Fish density and biomass were closely related to basin area regardless of the number of fish species, probably because increases in stream width with increasing basin area increased the amount of habitat available. In the Mangaotama Stream, fish density and biomass were similar to density and biomass in east coast rivers of the North Island, despite the greater number of species at east coast sites (Rowe et al. 1999). Habitat also controlled the distribution of shortfinned eels, torrentfish, and shortjawed kokopu (Galaxias postvectis) in rivers of the West Coast of the South Island (Jowett et al. 1996).

Fish densities in the Mangaotama Stream generally fell within the range of those previously reported for New Zealand using similar sampling techniques (4.5-252 fish $100 \mathrm{~m}^{-2}$; Jowett \& Richardson 1996; Rowe et al. 1999), except for the most downstream site in this study (M8), which had
459 fish $100 \mathrm{~m}^{-2}$. The high density of shortfinned eels at M8 was probably attributable to the highly suitable habitat and not to the small increase in basin area between M5 $\left(19.3 \mathrm{~km}^{2}\right)$ and M8 $\left(21.2 \mathrm{~km}^{2}\right)$.

Eel biomasses in Waikato streams are very high by world standards. The previous maximum reported for the Waikato region (168 $\mathrm{g} \mathrm{m}^{-2}$; Hicks \& McCaughan 1997) was exceeded by site M8 in the Mangaotama Stream at which shortfinned eels were present at $206 \mathrm{~g} \mathrm{~m}^{-2}$. These figures exceed those given for the tropical Amazon River in Venezuela $\left(160 \mathrm{~g} \mathrm{~m}^{-2}\right)$ and the Kafue River in Zambia (52 $\mathrm{g} \mathrm{m}^{-2}$; Randall et al. 1995). Eel biomass in the Mangaotama Stream was much greater than in similar-sized coastal streams (0.16-1.0 $\mathrm{g} \mathrm{m}^{-2}$; Glova et al. 1998), possibly because the Mangaotama Stream is part of the much larger Waikato River.

Crayfish (Paranephrops planifrons) were present in the Mangaotama Stream at all sites, but in contrast to fish, crayfish lineal density did not show any association with basin area; areal density was, in fact negatively related to basin area. This negative relationship suggests that crayfish use primarily edge habitat with its low velocities, confirming Riordan's (2000) conclusions for Waikato and Coromandel streams. In the South Island of New Zealand, density of $P$. zealandicus adults were negatively associated with current velocity, and juveniles were positively associated with coarse substrates (Usio \& Townsend 2000). In the Mangaotama Stream, such physical characteristics were more common in headwater and edge habitats than in mid-channel at downstream sites. It is also possible that crayfish numbers were underestimated because of the section lengths that were fished in the Mangaotama Stream. For efficient capture of crayfish by electroshocking, very intensive electroshocking is necessary (e.g., Rabeni et al. 1997), which is possible only in short sections. Thus, Mangaotama Stream estimates of crayfish are relative rather than absolute abundances.

I conclude that barriers to migration and distance inland controlled the number of fish species in the Mangaotama Stream, whereas abundance of fish (density and biomass of all species combined) was related to basin area. Native species dominated the fish fauna despite the open access of the lower stream reaches to introduced salmonids such as brown trout. In light of the high densities, biomass, and number of fish species seen in the lower sites, it seems that the native fish are better adapted to the habitat conditions presented by the mixture of land uses than are introduced species such as trout. 


\section{ACKNOWLEDGMENTS}

I thank Grant Barnes and Shaun Clements for assistance with the field sampling. Lee Laboyrie and Shona Duncan assisted with sample processing in the laboratory. John Quinn of the National Institute of Water and Atmospheric Research (NIWA), Hamilton, kindly provided the data for stream discharge in November and channel gradient in Table 1. Gordon Glova, Ian Jowett, Jody Richardson, Bob McDowall, and Gerry Closs provided critical reviews of the manuscript. C. M. King provided important editorial input. This project was entirely funded by a grant from the University of Waikato Research Committee.

\section{REFERENCES}

Allen, K. R. 1961: Relations between Salmonidae and the native freshwater fauna in New Zealand. Proceedings of the New Zealand Ecological Society 8: 66-70.

Armour, C. L.; Burnham, K. P.; Platts, W. S. 1983: Field methods and statistical analyses for monitoring small salmonid streams. U. S. Fish and Wildlife Service FWS/OBS-83/33.

Boubée, J.; Jowett, I.; Nichols, S.; Williams, E. 1999: Fish passage at culverts: a review, with possible solutions for New Zealand indigenous species. Wellington, Department of Conservation.

Chadderton, W. L.; Allibone, R. M. 2000: Habitat use and longitudinal distribution patterns of native fish from a near pristine Stewart Island, New Zealand stream. New Zealand Journal of Marine and Freshwater Research 34: 487-499.

Chapman, M. A. 1996: Human impacts on the Waikato River system, New Zealand. GeoJournal 40(12): 85-99.

Cushing, C. E.; Cummins, K. W.; Minshall, G. W. ed. 1995: Ecosystems of the world 22. River and stream ecosystems. Amsterdam, Elsevier.

Davies-Colley, R. J. 1997: Stream channels are narrower in pasture than in forest. New Zealand Journal of Marine and Freshwater Research 31: 599-608.

Department of Lands and Survey 1979: New Zealand topographical map 1:50 000 NZMS 260 sheet S14 Hamilton. 1st ed. Wellington, Department of Lands and Survey.

Dudgeon, D. 1995: The ecology of rivers and streams in tropical Asia. In: Cushing, C. E.; Cummins, K. W.; Minshall, G. W. ed. Ecosystems of the world 22. River and stream ecosystems. Amsterdam, Elsevier. Pp. 615-756.
Gehrke, P. C.; Harris, J. H. 2000: Large-scale patterns in species richness and composition of temperate riverine fish communities, south-eastern Australia. Marine and Freshwater Research 51: 165-182.

Glova, G. J.; Jellyman, D. J.; Bonnett, M. L. 1998: Factors associated with the distribution and habitat of eels (Anguilla spp.) in three New Zealand lowland streams. New Zealand Journal of Marine and Freshwater Research 32: 255-269.

Hanchet, S. 1990: Effect of land use on the distribution and abundance of native fish in tributaries of the Waikato River in the Hakarimata range, North Island, New Zealand. New Zealand Journal of Marine and Freshwater Research 24: 159-171.

Hawkes, H. A. 1975: River zonation and classification. In: Whitton, B. A. ed. Studies in ecology, vol. 2: river ecology. Berkeley, University of California Press. Pp. 312-374.

Hayes, J. W.; Leathwick, J. R.; Hanchet, S. M. 1989: Fish distribution patterns and their association with environmental factors in the Mokau River catchment, New Zealand. New Zealand Journal of Marine and Freshwater Research 23: 171180.

Hicks, B. J.; McCaughan, H. M. C. 1997: Land use, associated eel production, and abundance of fish and crayfish in streams in Waikato, New Zealand. New Zealand Journal of Marine and Freshwater Research 31: 635-650.

Hynes, H. B. N. 1970: The ecology of running waters. Liverpool, Liverpool University Press.

Huet, M. 1959: Profiles and biology of western European streams as related to fish management. Transactions of the American Fisheries Society 88: 155-163.

Illes, J. 1961: Versuch einer allgemein biozönotischen Gleiderung der Fliessgewässer. Internationale Revue der gesamten Hydrobiologie 46: 205-213.

Jowett, I. G.; Richardson, J. 1996: Distribution and abundance of freshwater fish in New Zealand rivers. New Zealand Journal of Marine and Freshwater Research 30: 239-255.

Jowett, I. G.; Richardson, J.; McDowall, R. M. 1996: Relative effects of in-stream habitat and land use on fish distribution in tributaries of the Grey River, New Zealand. New Zealand Journal of Marine and Freshwater Research 30: 463-475.

Joy, M. K.; Henderson, I. M.; Death, R. G. 2000: Diadromy and longitudinal patterns of upstream penetration of freshwater fish in Taranaki, New Zealand. New Zealand Journal of Marine and Freshwater Research 34: 531-543. 
McDowall, R. M. 1984: Exotic fishes: the New Zealand experience. In: Courtenay, W. R.; Stauffer, J. R. $e d$. Distribution, biology, and management of exotic fishes. Baltimore, Johns Hopkins University Press. Pp. 200-214.

McDowall, R. M. 1993: Implications of diadromy for the structuring and modelling of riverine fish communities in New Zealand. New Zealand Journal of Marine and Freshwater Research 27: 453-462.

Oberdorff, T.; Guilbert, E.; Lucchetta, J-C. 1993: Patterns of fish species richness in the Seine River basin, France. Hydrobiologia 259: 157-167.

Osterkamp, W. R.; Hedman, E. R. 1977: Variation of width and discharge for natural high-gradient stream channels. Water Resources Research 13: 256-258.

Parkyn, S. M. 2000: Effects of native forest and pastoral land use on the population dynamics and trophic role of the New Zealand freshwater crayfish Paranephrops planifrons (Parastacidae). PhD thesis, University of Waikato, Hamilton.

Pearson, C. P. 1992: Analysis of floods and low flows. In: Mosley, M. P. ed. Waters of New Zealand. Wellington, New Zealand Hydrological Society. Pp. 95-116.

Quinn, J. M.; Cooper, A. B. 1997: Land-water interactions at Whatawhata, New Zealand: introduction and synthesis. New Zealand Journal of Marine and Freshwater Research 31: 569-577.

Quinn, J. M.; Cooper, A. B.; Davies-Colley, R. J.; Rutherford, J. C.; Williamson, R. B. 1997: Landuse effects on habitat, water quality, periphyton, and benthic invertebrates in Waikato, New Zealand, hill-country streams. New Zealand Journal of Marine and Freshwater Research 31: 579-597.

Rabeni, C. F.; Collier, K. J.; Parkyn, S. M.; Hicks, B. J. 1997: Evaluating techniques for sampling stream crayfish (Paranephrops planifrons). New Zealand Journal of Marine and Freshwater Research 31: 693-700.
Randall, R. G.; Kelso, J. R. M.; Minns, C. K. 1995: Fish production in freshwaters: are rivers more productive than lakes? Canadian Journal of Fisheries and Aquatic Sciences 52: 631-643.

Richards, K. 1982: Rivers, form and process in alluvial channels. London, Methuen.

Richardson, J.; Jowett, I. 1996: How does your catch measure up? Water \& Atmosphere 4: 17-19.

Riordan, P. 2000: Population dynamics, habitat analysis and food assimilation in the freshwater crayfish Paranephrops planifrons in a North island stream. MSc thesis, University of Waikato, Hamilton.

Rowe, D. K.; Chisnall, B. L.; Dean, T. L.; Richardson, J. 1999: Effects of land use on native fish communities in east coast streams of the North Island of New Zealand. New Zealand Journal of Marine and Freshwater Research 33: 141-151.

SPSS 2000: SYSTAT 10 Statistics I. Chicago, SPSS.

Swales, S.; West, D. W. 1991: Distribution, abundance and conservation status of native fish in some Waikato streams in the North Island of New Zealand. Journal of the Royal Society of New Zealand 21: 281-296.

Townsend, C. R.; Crowl, T. A. 1991: Fragmented population structure in a native New Zealand fish: an effect of introduced brown trout? Oikos 61: 347-354.

Usio, N.; Townsend, C. R. 2000: Distribution of the New Zealand crayfish Paranephrops zealandicus in relation to stream physico-chemistry, predatory fish, and invertebrate prey. New Zealand Journal of Marine and Freshwater Research 34: 557-567.

White, G. C.; Anderson, D. R.; Burnham, K. P. 1982: Capture-recapture methods for sampling closed populations. LA-8787-NERP, Los Alamos National Laboratory, Los Alamos, New Mexico. 